\title{
QUALITY STUDY AND IMPROVEMENT OF LOGISTIC PROCESSES ON THE EXAMPLE OF A CHOSEN ENTERPRISE
}

\author{
Michał MOLENDA \\ Silesian University of Technology
}

\begin{abstract}
:
This article presents the issues of quality research and improvement of logistics processes in the area of distribution of one of selected industrial enterprises. The case described concerns the producer of raw chemical materials, who acts as a supplier for industrial customers. The studied company, due to dynamic changes in product demand, very often outsources the distribution of raw materials to external transport companies. This solution results in limited supervision over commissioned processes, which may lead to increased probability of customer dissatisfaction. The article presents the results of the study of the quality of logistic processes implemented or commissioned in the examined enterprise. The assessment was based on the results of the customer satisfaction survey and the results of the analysis of received complaints regarding deliveries. Analysis of the causes of complaints allowed to identify the actions necessary to improve the quality of logistics processes. This article contains, among others, the criteria for the assessment of transport service providers and a set of recommendations to reduce the risks associated with logistics processes of deliveries.
\end{abstract}

Key words: quality of logistics processes, quality of deliveries, improvement, quality

\section{INTRODUCTION}

Quality management in a business organization, in addition to ensuring the compliance of products with the established requirements, is aimed at continuous improvement of the company's processes. Improving processes means improving their quality, effectiveness and proficiency $[1,2,3,4]$. This action also applies to logistics processes. The logistic process is a system of interrelated operations aimed at the flow of physical objects and related information. Practically, in every company operating on the market such processes can be identified. It is difficult to look for an industrial enterprise without processes such as storing, packing, marking, loading, carriage, reloading, unloading [5]. The mentioned processes determine the efficiency of the company's operation and affect its competitiveness. That is why, as stated in the literature, one of the main parts of logistics is to constantly reduce the costs of logistics processes [6]. This applies to both logistic processes of supply and distribution. In microeconomic terms, distribution refers to the process of selling and delivering products of a selected enterprise through intermediaries to final buyers [7]. Logistics of distribution in the enterprise, in addition to tasks related to the physical movement of products to the customer, also includes a number of activities that attempt to achieve full customer satisfaction. These activities constitute logistic customer service, which aims to create a positive relationship between the company and its clients, which results in longterm, efficient cooperation bringing tangible benefits to both parties [8]. Therefore, logistics processes in the distribution area should firstly be improved in terms of their quality. In the case of distribution logistics, the requirements in the form of timeliness, security and completeness of deliveries are extremely important. In order to efficiently complete the entire transport process, it is necessary to cooperate with the supplier and the customer during the implementation of logistic processes [9]. Lack of quality of logistic processes: any deviations from the requirements such as untimely transport, loss, damage to cargo, unprofessional service - all generate additional costs and customer dissatisfaction [10, 11, 12, 13, 14, 15]. This article presents the issues of quality research and improvement of logistics processes in the area of distribution of one of selected industrial enterprises. The case described concerns the producer of raw chemical materials, who acts as a supplier for industrial customers. The studied company, due to dynamic changes in product demand, very often outsources the distribution of raw materials to external transport companies. This solution results in limited supervision over commissioned processes, which may lead to increased probability of customer dissatisfaction. The article presents the results of the study of the quality of logistic processes implemented or commissioned in the examined enterprise. The assessment was based on the results of the customer satisfaction survey and the results of the analysis of received complaints regarding deliveries. Analysis of the causes of complaints allowed to identify the actions necessary to improve 
the quality of logistics processes. This article contains, among others, the criteria for the assessment of transport service providers and a set of recommendations to reduce the risks associated with logistics processes of deliveries.

\section{ASSESSMENT OF QUALITY OF LOGISTIC PROCESSES IN THE BUSINESS ACTIVITIES}

The measured company is one of the leading producers in the chemical industry in Europe. The company also operates as a supplier of chemical raw materials for industrial clients. The company gained its competitive position due to the care for the high quality of products and services offered. The implementation of this pro-quality policy requires having reliable information about the client and his needs. Therefore, the analysed company very carefully examines the expectations of customers and their satisfaction with the cooperation so far. The main purpose of the research is to determine:

- Key expectations of clients,

- Customer requirements and margin of tolerance,

- Customer's assessment of the quality of the company's operations,

- Assessing the quality of the company's performance compared to clients' priorities,

- Evaluation of the quality of the company's activity in comparison with the quality of competition activities,

- Priorities to improve the organization's operations.

The wide range of activities determines the necessity of conducting multi-criteria quality tests. Therefore, the company examines the quality of its products and services among clients based on several criteria. Figure 1 presents the results of the quality assessment survey of selected aspects of the company's operations. These are crucial for customers. Full customer satisfaction is expressed through a $100 \%$ value of the indicator.

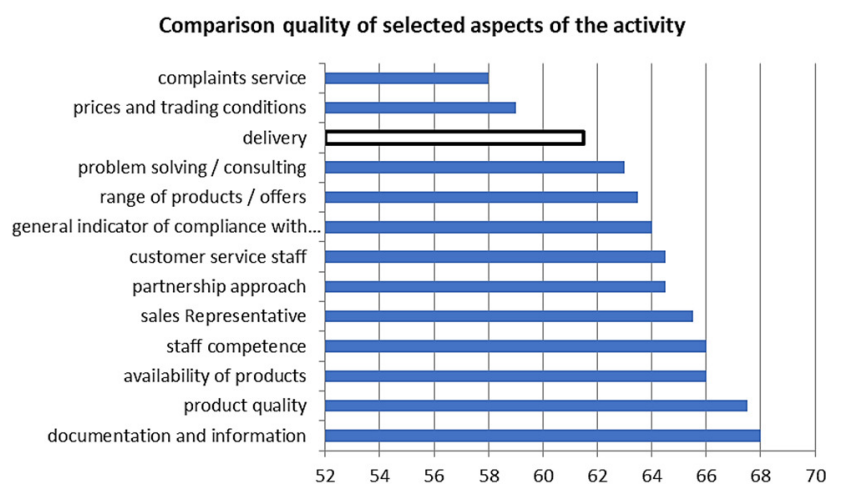

Fig. 1 Comparison quality of selected aspects of the activity Source: [16]

The data presented show that the overall compliance rate is $64 \%$. One of the rated aspects of business activity is the quality of deliveries (61.5\%). In this aspect, the clients evaluate the quality of logistics processes carried out while delivering the goods to the customer. The quality of deliveries is of key importance for the total assessment of the quality of cooperation with the client. In the analysed company, the way of delivering goods to the customer affects not only the quality of the transported raw material, but also its security, timely deliveries and customer service. Damage or contamination of the raw material during transport, untimely delivery or unprofessional behavior of the carrier drastically reduce the overall assessment of the quality of the contract. It is worth noting that the processes of delivering orders to the customer are usually outsourced to forwarding companies. Therefore, special supervision over these processes is required.

In order to assess the quality of deliveries, the company analysed the complaints that were received during one quarter of 2015 . About $30 \%$ of all complaints reported to the company concerned the quality of carriages. The largest amount of the complaints mentioned as almost $90 \%$ related to transport-related problems. In order to find out the reasons for such an assessment, an analysis of formally submitted complaints in this area of activity has been made. Most often they concerned:

- delayed shipment,

- incomplete order,

- damaged product or packaging,

- rudeness of the carrier,

- failure to secure the means of transport with a seal,

- the wrong type of packaging,

- inappropriate protection during transport.

Reported complaints have been thoroughly analysed. Data for analysis were grouped due to the category and type of complaint. The grouped data together with the short characterization and effects of the problem are presented in Table 1.

Table 1 Summary of the causes of complaints regarding logistic processes in the examined enterprise

\begin{tabular}{|c|c|c|c|}
\hline 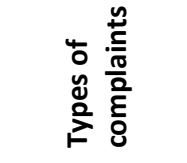 & 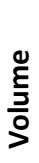 & 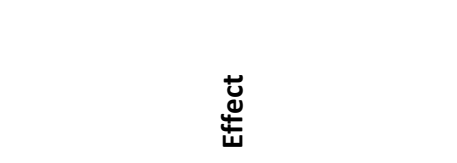 & 仓ัّ \\
\hline $\begin{array}{l}\text { theft of the } \\
\text { product }\end{array}$ & 1 & $\begin{array}{l}\text { the customer notifying the lack of } \\
\text { goods, the necessity of re-dispatch } \\
\text { and reporting the case to the police } \\
\text { and damages to the supplier. }\end{array}$ & $\begin{array}{l}\text { very } \\
\text { high }\end{array}$ \\
\hline $\begin{array}{l}\text { delay of de- } \\
\text { livery }\end{array}$ & 6 & $\begin{array}{l}\text { attention from the client, customer } \\
\text { charges, production stoppage at } \\
\text { the customer's. }\end{array}$ & high \\
\hline $\begin{array}{l}\text { incorrect lo- } \\
\text { ading }\end{array}$ & 2 & $\begin{array}{l}\text { return of the wrong product, ne- } \\
\text { cessity of fast shipment of ordered } \\
\text { goods. }\end{array}$ & $\begin{array}{l}\text { me- } \\
\text { dium }\end{array}$ \\
\hline $\begin{array}{l}\text { problem with } \\
\text { unloading }\end{array}$ & 2 & $\begin{array}{l}\text { the necessity of using specialist } \\
\text { equipment for unloading or reload- } \\
\text { ing to another means of transport. }\end{array}$ & low \\
\hline damage to & & refusal to accept the goods by the & \\
\hline $\begin{array}{l}\text { the packa- } \\
\text { ging / pro- } \\
\text { duct }\end{array}$ & 8 & $\begin{array}{l}\text { customer - return to the ware- } \\
\text { house, reimbursement for dam- } \\
\text { aged goods, disposal. }\end{array}$ & high \\
\hline $\begin{array}{l}\text { contamina- } \\
\text { tion of the } \\
\text { packaging / } \\
\text { product }\end{array}$ & 5 & $\begin{array}{l}\text { refusal to accept the goods by the } \\
\text { customer - return to the ware- } \\
\text { house, discount for contaminated } \\
\text { goods, the cost of disposal, the cost } \\
\text { of quality control. }\end{array}$ & $\begin{array}{l}\text { me- } \\
\text { dium/ } \\
\text { high }\end{array}$ \\
\hline $\begin{array}{l}\text { destruction } \\
\text { of the pro- } \\
\text { duct }\end{array}$ & 2 & $\begin{array}{l}\text { disposal, re-dispatch and reporting } \\
\text { of damage to the supplier. }\end{array}$ & $\begin{array}{l}\text { very } \\
\text { high }\end{array}$ \\
\hline
\end{tabular}


The complaints mentioned in Table 2 have been arranged according to the number of applications for a given type of complaint. For such ordered data Pareto analysis was carried out (Fig. 2).

Table 2

Types and number of complaints in the examined period

\begin{tabular}{|c|c|c|c|c|}
\hline Id. & Types of complaints & Volume & $\begin{array}{c}\text { Volume } \\
\text { [\%] }\end{array}$ & $\begin{array}{l}\text { Running } \\
\text { total [\%] }\end{array}$ \\
\hline A & $\begin{array}{l}\text { damage to the packa- } \\
\text { ging/product }\end{array}$ & 8 & 30.8 & 30.8 \\
\hline B & delay of delivery & 6 & 23.1 & 53.8 \\
\hline C & $\begin{array}{l}\text { contamination of the } \\
\text { packaging/product }\end{array}$ & 5 & 19.2 & 73.1 \\
\hline D & $\begin{array}{l}\text { destruction of the } \\
\text { product }\end{array}$ & 2 & 7.7 & 80.8 \\
\hline$E$ & incorrect loading & 2 & 7.7 & 88.5 \\
\hline $\mathrm{F}$ & $\begin{array}{l}\text { problem with unlo- } \\
\text { ading }\end{array}$ & 2 & 7.7 & 96.2 \\
\hline G & $\begin{array}{l}\text { theft of the product } \\
\text { Total: }\end{array}$ & $\begin{array}{c}1 \\
26\end{array}$ & 3.8 & 100.0 \\
\hline
\end{tabular}

Source: [16].

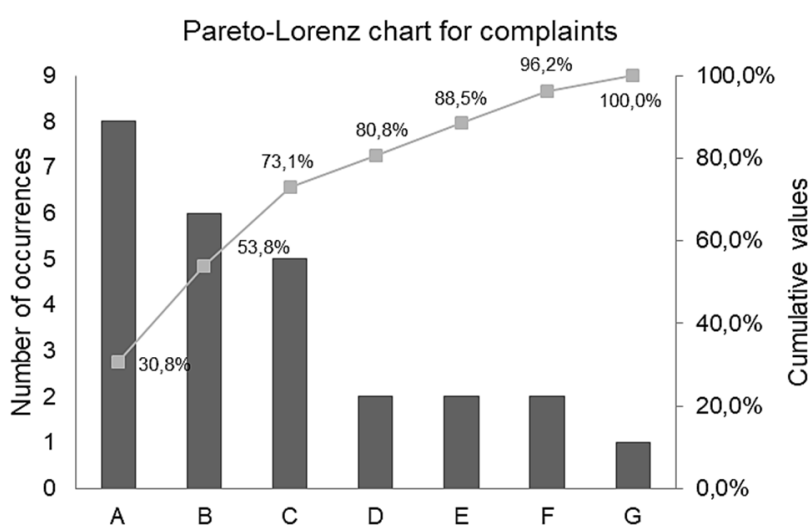

Fig. 2 Pareto chart of complaints types

Damage to the packaging or product, delay in delivery, contamination of the product - altogether account for $73 \%$ of the total number of all complaints in the area of deliveries. Considering the significant costs that these types of events generate, the reasons for their existence were identified first. As a result of a thorough analysis it was found that the reasons for the complaint are related to [16]:

- internal and external communication of the company between: customer - trader - customer service - production - warehouse - transport company - driver,

- quality control of products and packaging,

- means of securing the product during transport,

- spotlessness control of the means of transport,

setting the requirements for the means of transport.

The analysed case proved that the majority of complaints have their source in an imperfect communication system between the analysed company and transport companies. In addition, it was established that the main source of complaint is the so-called human factor - in particular, insufficient involvement of employees of external transport companies. Information exchange and the human factor have proved to be the most risk causing factors.

It is worth emphasizing that the creation of complaints is influenced by dynamic changes in demand, which make it very difficult to plan logistic processes in the area of deliveries. The sudden increase in the number of orders means that the surveyed company is forced to use the services of carriers that are not thoroughly verified for the quality of services provided, or do not have sufficient experience in transportation of chemical raw materials.

\section{THE CONCEPTUAL PROCESS OF PERFORMANCE PERFEC- TING}

As a result of the analysis of the causes of the complaint, it was established that it is necessary to develop and implement the concept of connection of IT systems in the area of customer and carrier supply management. Employees of the customer service department of the analysed company are to be given the opportunity to view the consumption of the raw material in customer stores. This would facilitate planning of dates and levels of delivery, and most importantly, it would allow to qualify and select appropriate carriers.

In the further part of conceptual improvement it was established that carriers will be subject to annual evaluation in terms of the quality of cooperation. The assessment will be based on the opinion of customers and employees of the customer service and logistics department of the examined enterprise. The assessment of the quality of cooperation with the carrier will consist of events such as:

- late loading and unloading,

- irregularities during transport, e.g. lack of required equipment, documentation, unprofessional behavior of the driver,

- damage or loss of goods.

In addition, a mandatory assessment of the qualifications of carriers has been introduced. For this purpose, transparent criteria for the assessment of transport service providers have been defined. These companies will be evaluated in the following categories [16]:

- carrier's experience in the transport market segment,

- communication with the carrier, availability of communication, etc.,

- professionalism (knowledge and competence) of operational personnel,

speed of reaction regarding taking orders,

- delivery of transport services in relation to the requirements set for the transport order,

- quality and technical condition of the carrier's mechanical stock (no returns/complaintsdue to damage in transport),

- the carrier's ability to respond flexibly to new needs, unplanned situations, e.g. new service delivery rules, special surveillance shipments (increased delivery intensity, etc.),

- adaptation of carrier's services to individual customer needs (non-standard requirements),

- speed and reliability of information regarding the status of transport orders (shipment monitoring),

- delivery of transport services in relation to the requirements set out on the transport order (keeping the date of loading, unloading, equipment required), 
- the carrier's corrective actions in the event of damage, as well as the manner of conduct in the aspect of recommended corrective actions.

Assessment of qualifications of transport service providers will allow to determine the list of qualified suppliers who will be recommended for cooperation. Preferred will be carriers with formal qualifications in the form of a certificate, eg ISO 28000 or having certified cargo securing systems. This solution will improve the quality of deliveries and minimize the number of damages and contamination of the product being transported. These events will also be eliminated by changing internal practices and procedures in the company under study. The process of selecting the means of transport was formalized to suit the client's preferences. Requirements such as:

- a guarantee of maintaining the temperature of the cargo,

- a guarantee of on time delivery,

- side unloading,

- prohibition of using a walking-stick type vehicle that often causes contamination of the packaging/product. In addition, mandatory quality control of the packaging has been introduced prior to shipment and inspection of the cleanliness of the means of transport needs to be undertaken before loading of product. The warehouse service should control the condition of the transport means arrived at based on the established checklist on every occasion. Each means of transport should be clean, fitted and dry, without external odors. It is forbidden to get atmospheric precipitation inside, also in the case of car tarpaulins the floor cannot be contaminated/damaged.

In addition, before loading warehousemen are obliged to:

- inspection of the shipping documents to verify the correctness of loading,

- obtaining written confirmation from the driver, no objections to loading.

For the purpose of risk limiting there are also plans to introduce photographic documentation during the described inspection and loading.

\section{CONCLUSION}

The subject of the quality of logistics processes in the area of distribution, especially in B2B relations, is complex and multidimensional. The production company, also acting as a supplier in such a system, should not only have the right product, but it is obliged to deliver this product to the customer in a timely manner, without loss of value and at an acceptable level of cooperation. Quality assurance is undoubtedly a more difficult challenge if the supplier outsources the transport process to other entities, e.g. transport companies. That is why the correct selection of forwarding companies is extremely important. It is possible only on the basis of transparent criteria that will allow an objective assessment of the qualifications of these entities. It is not without significance to tighten cooperation and joint training actions for carriers and their drivers. Monitoring the quality of logistic processes outsourced is another task for the analysed enterprise. Recording the unwanted events such as delivery delay, damage to the packaging/product, and contamination is necessary. Thanks to this, risky carriers will be eliminated.

Process improvement Logistics is a particularly labor-intensive and costly activity. Mainly because these are processes with a complex formal structure. The wide structure of entities and organizational units involved in the planning, organizing or delivery process requires access to dynamically changing data and information. In the case of long-term cooperation, the modification and integration of the IT systems of the producer/supplier, carrier and customer seems to be the recommended solution.

\section{ACKNOWLEDGMENT}

This article was created as part of the implementation of the statutory work of the number: 13/030/BK_18/0039

\section{REFERENCES}

[1] Wojtaszak M., Biały W. Measurement system analysis of attribute or continuous data, as a one of the first steps in Lean Six Sigma projects. In: Systems Supporting Production Engineering. Ed. Jan Kaźmierczak. Wydawnictwo PA NOVA S.A., Gliwice, 2013.

[2] Książek D., Ligarski M.J. The role of the factory production control in the improvement of products and processes. Systemy Wspomagania w Inżynierii Produkcji No. 4, 2016.

[3] Ligarski M.J.: Problem identification method in certified quality management systems. Quality \& Quantity. No. 46, 2012.

[4] Midor K. Use of Six Sigma in the production process - case study; Systemy Wspomagania w Inżynierii Produkcji vol. 6 iss. 4, 2017

[5] Matwiejczuk R. (red.): Integracja marketingu $i$ logistyki - wybrane problemy. Oficyna Wydawnicza Politechniki Opolskiej, Opole, 2005

[6] Gołembska E. Podstawy logistyki. Wydawnictwo Naukowe Wyższej Szkoły Kupieckiej, Łódź, 2006

[7] Włodarczyk E., Rybak A.. Logistyka dystrybucji w przedsiębiorstwach górniczych; Systemy Wspomagania w Inżynierii Produkcji vol. 6 iss. 2. 2017

[8] Zarzycka A.M., Systemy dystrybucji w eksporcie, Wydawnictwo Szkoły Głównej Handlowej w Warszawie, Warszawa 2008.

[9] Odlanicka-Poczobutt M., Kulińska E.; Determinanty procesów planowania transportu wyrobów piwowarskich - studium przypadku; Logistyka 6/2015.

[10] Franceschini F., Rafele C.; Quality evaluation in logistic services; International Journal of Agile Management Systems 2/1; 2000.

[11] Mentzer, J.T., Flint, D.J. and Hult, T.M.; Logistics service quality as a segment-customized process; Journal of Marketing, Vol. 65 No. 4, 2001

[12] Millen R., Sohal A., Moss S.; Quality management in the logistics function: an empirical study; International Journal of Quality \& Reliability Management 16 (2), 1999. 
[13] Parasuraman, A. and Grewal, D., The impact of technology on the quality-value-loyalty chain: a research agenda, Journal of Academy of Marketing Science, Vol. 28 No. 1, 2000.

[14] Rafid, M. and Jaafar, H.S., Measuring customers' perceptions of logistics service quality of 3PL service providers", Journal of Business Logistics, Vol. 28 No. 2, 2007.

\section{dr inż. Michał Molenda}

Silesian University of Technology Faculty of Organization and Management Institute of Production Engineering 26 Roosevelta Street., 41-800 Zabrze, Poland e-mail: michal.molenda@polsı.pl
[15] Rahman, S., Quality management in logistics: an examination of industry practices", Supply Chain Management: An international Journal, Vol. 11 No. 3, 2006.

[16] Wójcik K., Analiza i doskonalenie procesów logistycznych w wybranym przedsiębiorstwie przemysłowym - Praca magisterska, Wydział Organizacji i Zarzadzania, Politechnika Śląska, Gliwice, 2017. 